\title{
Shearogovea, a New Genus of Cyphophthalmi (Arachnida, Opiliones) of Uncertain Position from Oaxacan Caves, Mexico
}

\section{Citation}

Giribet, Gonzalo. 2011. “Shearogovea, a New Genus of Cyphophthalmi (Arachnida, Opiliones) of Uncertain Position from Oaxacan Caves, Mexico." Breviora 528 (November 11): 1-7. doi: $10.3099 / 528.1$.

\section{Published Version}

doi:10.3099/528.1

\section{Permanent link}

http://nrs.harvard.edu/urn-3:HUL.InstRepos:34872804

\section{Terms of Use}

This article was downloaded from Harvard University's DASH repository, and is made available under the terms and conditions applicable to Other Posted Material, as set forth at http:// nrs.harvard.edu/urn-3:HUL.InstRepos:dash.current.terms-of-use\#LAA

\section{Share Your Story}

The Harvard community has made this article openly available.

Please share how this access benefits you. Submit a story.

\section{Accessibility}




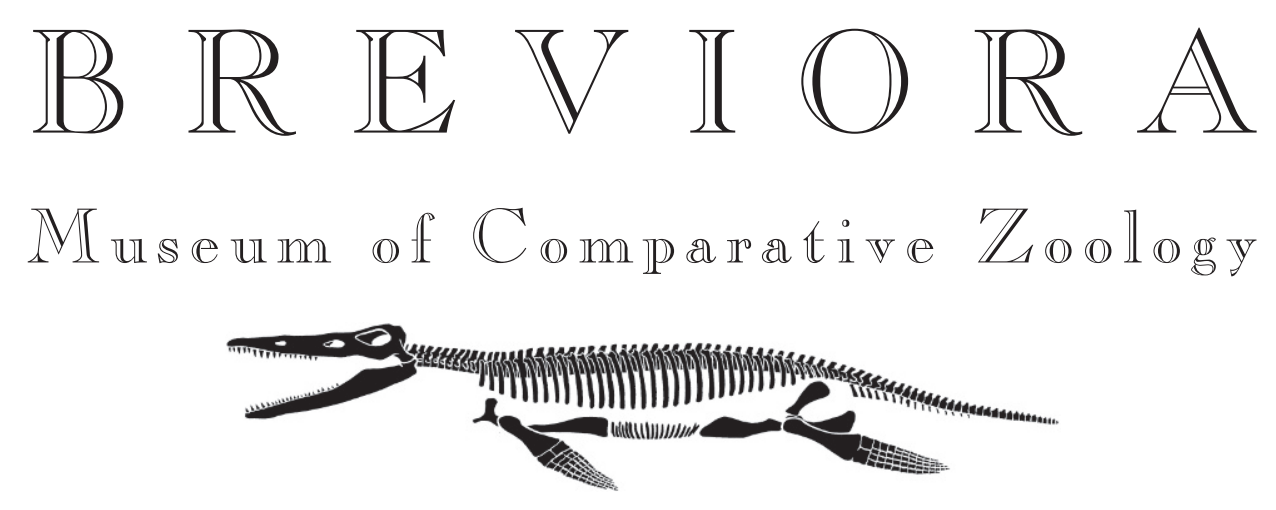

US ISSN 0006-9698

\begin{tabular}{lll}
\hline Cambridge, Mass. & 11 November 2011 & Number 528 \\
\hline
\end{tabular}

\section{SHEAROGOVEA, A NEW GENUS OF CYPHOPHTHALMI (ARACHNIDA, OPILIONES) OF UNCERTAIN POSITION FROM OAXACAN CAVES, MEXICO}

GONZALO GiRiBET ${ }^{1}$

Abstract. Shearogovea gen. nov. is erected for Neogovea mexasca Shear, 1977, a troglobitic cyphophthalmid species from a cave system in Oaxaca, Mexico. The new genus does not show affinity to Neogovea Hinton, 1938, as it lacks the characteristic toothed claw of leg II or the fusion of the coxae of legs II to those of legs III (which are in turn fused to coxae of legs IV). Shearogovea gen. nov. is probably not related to other Neotropical neogoveid genera, but its exact phylogenetic position remains unresolved.

KeY words: troglobite; Mexico; new genus; Neogoveidae; Sironidae

\section{INTRODUCTION}

Shear (1977) reviewed the Neotropical genus Neogovea Hinton, 1938 and described two new species, N. kamakusa Shear, 1977 from Guyana, and N. mexasca Shear, 1977 from a cave in Oaxaca, Mexico. Additional information on the latter species, originally described for two female individuals, was provided in a later paper based on a larger collection of specimens, including males, from a nearby cave (Shear, 1980). In the same paper, a new familial system was

\footnotetext{
${ }^{1}$ Museum of Comparative Zoology, Department of Organismic and Evolutionary Biology, Harvard University, 26 Oxford Street, Cambridge, Massachusetts 02138, U.S.A.; e-mail: ggiribet@oeb.harvard.edu.
}

established for Cyphophthalmi, and Neogoveidae Shear, 1980 was designated for the genera Metagovea Rosas Costa, 1950, Parogovia Hansen, 1921 [misspelled as Paragovia] and Neogovea, including N. mexasca, despite acknowledging that it lacks characters used to diagnose the neogoveid genera (Shear, 1979).

The Mexican species differs from its supposed South American counterparts in several characters, also shared with the African Parogovia, later used to rediagnose Neogoveidae (Giribet, 2007b). Thus $N$. mexasca was considered of uncertain phylogenetic position in several studies (Giribet and Boyer, 2002; Schwendinger et al., 2004; Giribet and Kury, 2007; DaSilva et al., 2010) 

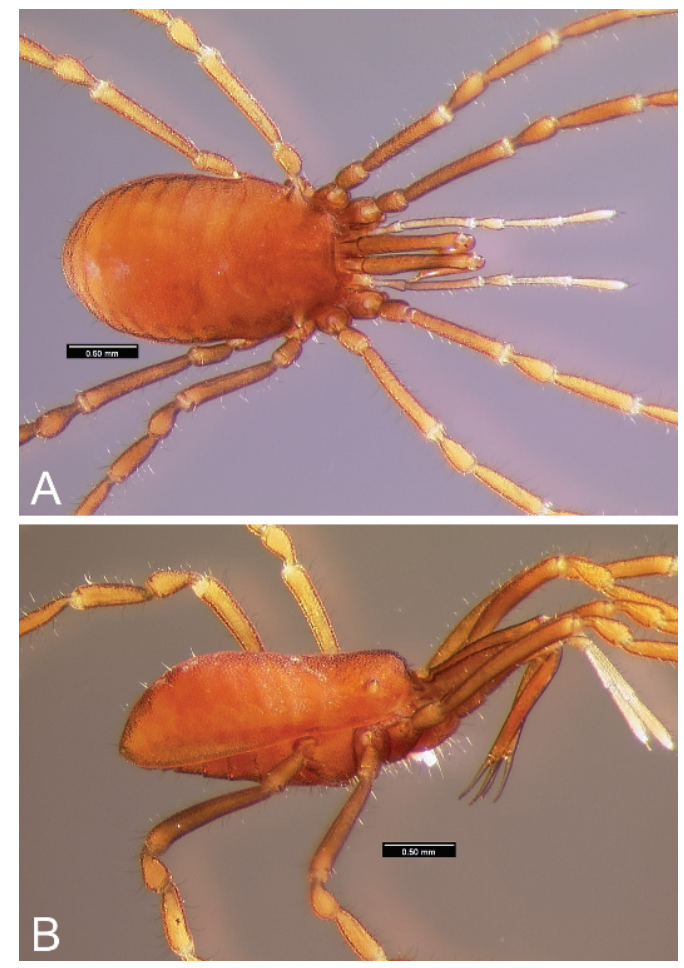

Figure 1. Shearogovea mexasca (Shear, 1977), female holotype, American Museum of Natural History. A, dorsal view; B, ventral view.

and recently excluded from Neogoveidae (Benavides and Giribet, 2007). However, some of these characters were considered adaptations to troglobite lifestyle, and was thus considered to be an aberrant neogoveid (Shear, 1979). Here, Shearogovea gen. nov. is erected for N. mexasca Shear, 1977 on the basis of detailed morphological analysis using scanning electron microscopy (SEM), but its familial assignment remains uncertain given the currently available data.

\section{MATERIALS AND METHODS}

The material used in this study belongs to the collection of the American Museum of Natural History and the Museum of Comparative Zoology. The holotype specimen
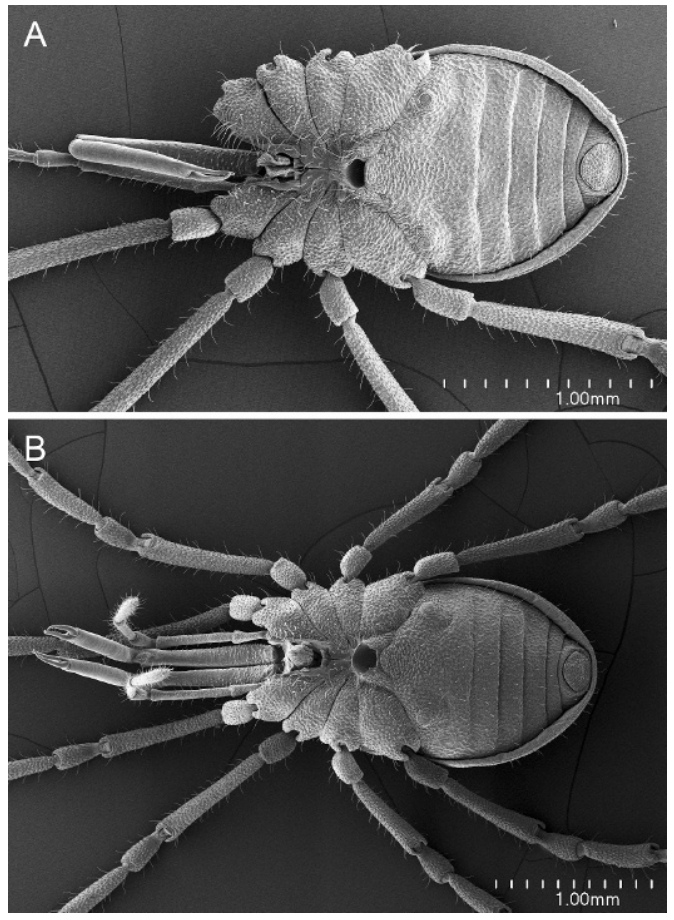

Figure 2. Shearogovea cf. mexasca from Cueva de la Finca. A, male, ventral view; B, female, ventral view.

was photographed using a JVC KY- F70B digital camera mounted on a Leica MZ 12.5 stereomicroscope. A series of images (about 10) were taken at different focal planes and assembled with the dedicated software package Auto-Montage Pro Version 5.00.0271 (Syncroscopy, Frederick, MD, USA). Scanning electron micrographs were taken with a Hitachi S4700 FE-SEM, after sputter coating with gold/palladium.

\section{Shearogovea Giribet, gen. nov. Figures 1-4}

Neogovea, Partim. Shear, 1977:172-175, figs. 16-24; Morales Soto, 1980:36-37; Shear, 1980:15-17, figs. 21-25; Cokendolpher and Lee, 1993:5; Rambla and Juberthie, 1994:217; Kury and Cokendolpher, 2000: 150-151; Giribet, 2000:71; Giribet and Boyer, 2002:110-116, 118, 121, 127-128; 

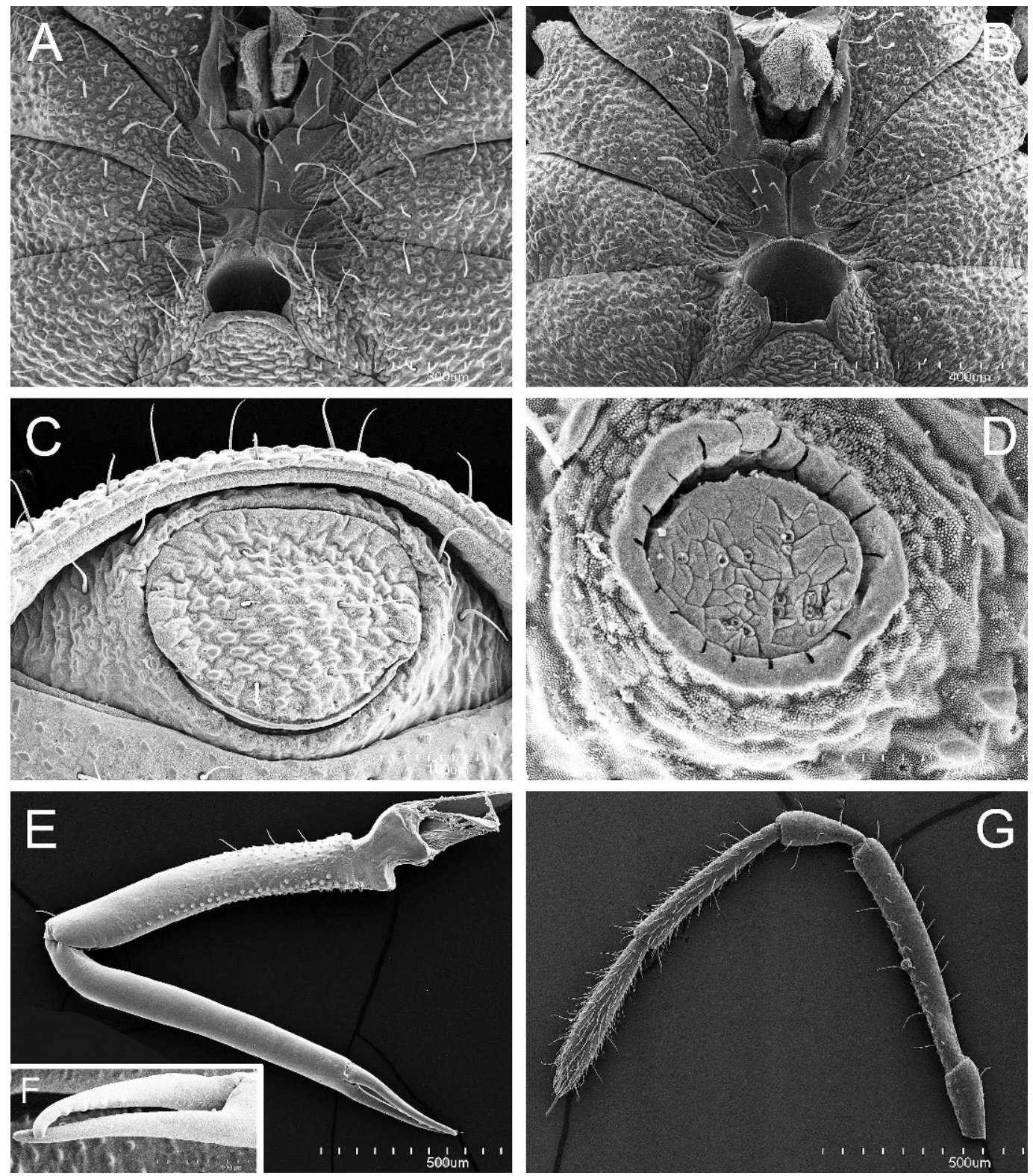

Figure 3. Shearogovea cf. mexasca from Cueva de la Finca. A, prosomal sternal complex, male; B, prosomal sternal complex, female; C, anal region, male; D, spiracle; E, left chelicer, male; F, detail of cheliceral fingers, male; $\mathrm{G}$, left palp, male. 
Giribet, 2007a:94; Jocqué and Jocqué, 2011:49.

'Neogovea'. Schwendinger et al., 2004: 1422; Benavides and Giribet, 2007:2.

"Neogovea". Giribet and Boyer, 2002:110 116, 118, 121, 127, 128; Giribet and Kury, 2007:68, 83; DaSilva et al., 2010:52.

Material Studied. The type material of $N$. mexasca consists of a female holotype and a female paratype from Cueva del Nacimiento del Río San Antonio, 10 km SSW of Acatlán de Pérez Figueroa, Oaxaca, Mexico, collected 31 December 1973 by James Reddell, William Elliott, and Roy Jameson, deposited in the American Museum of Natural History (Shear, 1977). Another collection from Cueva de la Finca, $10 \mathrm{~km} \mathrm{SW}$ of Acatlán de Pérez Figueroa, Oaxaca, Mexico, collected 31 December 1976 by James Reddell, David McKenzie, and Andy Grubs, also deposited in the American Museum of Natural History, includes five males and nine females. A male and a female mounted in SEM stubs have been transferred to the Museum of Comparative Zoology under accession numbers MCZ 124538 and 124539, respectively. No other collections of this or related species are known.

Diagnosis. Medium-sized cyphophthalmids with elongated appendages (Fig. 1), without eyes or eye lenses; ozophores of type 2 (sensu Juberthie, 1970) (Fig. 1B), entirely ornamented, with subterminal ozopore. Anterior margin of carapace concave dorsally, leaving the base of the chelicerae and the dorsal crest clearly exposed (Fig. 1A, B). Transverse prosomal sulcus inconspicuous (Fig. 1A). Transverse opisthosomal sulci present. Middorsal, longitudinal opisthosomal sulcus inconspicuous (Fig. 1A).

Coxae of leg II free, not fused to coxae of legs III (Figs. 2, 3A, B). Sternum absent (Figs. 2A, 3A). Proximal end of coxae I of males not meeting along the midline; all other coxae meeting along the midline; male gonostome semicircular, as large as the proximal ventral part of coxae of legs IV. Coxae II-III and III-IV with endites running along their suture. Anterior projections of male coxae IV endites on gonostome wall (Fig. 3A). Spiracles circular, of the closed type (Fig. 3D). Sternites 8 and 9 and tergite IX fused into a corona analis (Fig. 3C). Anal plate and anal region without conspicuous modifications or changes in ornamentation pattern. Opisthosomal exocrine glands of males absent (both sternal or anal glands). Hansen's organ absent.

Chelicerae of the protruding type (sensu Giribet, 2003) (Fig. 1A, B), with one dorsal and one basal process; with the basal and second cheliceral segments elongate, almost of uniform depth; first cheliceral segment ornamented at the first half, near the base, and in the ventral portion almost during its entire length; broadest part of second cheliceral segment neither near the base nor the joint with the cheliceral finger (Fig. 3E); dentition of mobile digit uniform (Fig. 3F). Palp trochanter without ventral process; first and second article of palp ornamented (Fig. 3G).

Metatarsus of all legs ornamented (Fig. 4A, D); tarsi of all legs smooth (Fig. 4A-G), without a distinct solea on leg I (Fig. 4C); claws of all legs smooth, without comblike modifications or lateral pegs (Fig. 4C-G). Tarsus IV of males not divided (Fig. 4A); Rambla's organ absent. Adenostyle conspicuous, thin, of the lamellar type (Fig. 4B); located in the first quarter of the tarsal length, but not in a basal position (Fig. 4A).

Spermatopositor with short ventral plate and without ventral microtrichiae, lacking moveable fingers (see Shear, 1980, figs. 24 25). Ovipositor typical, with terminal sense organs (Shear, 1977:174-175).

Included Species. Shearogovea mexasca (Shear, 1977) is the type and only species in 

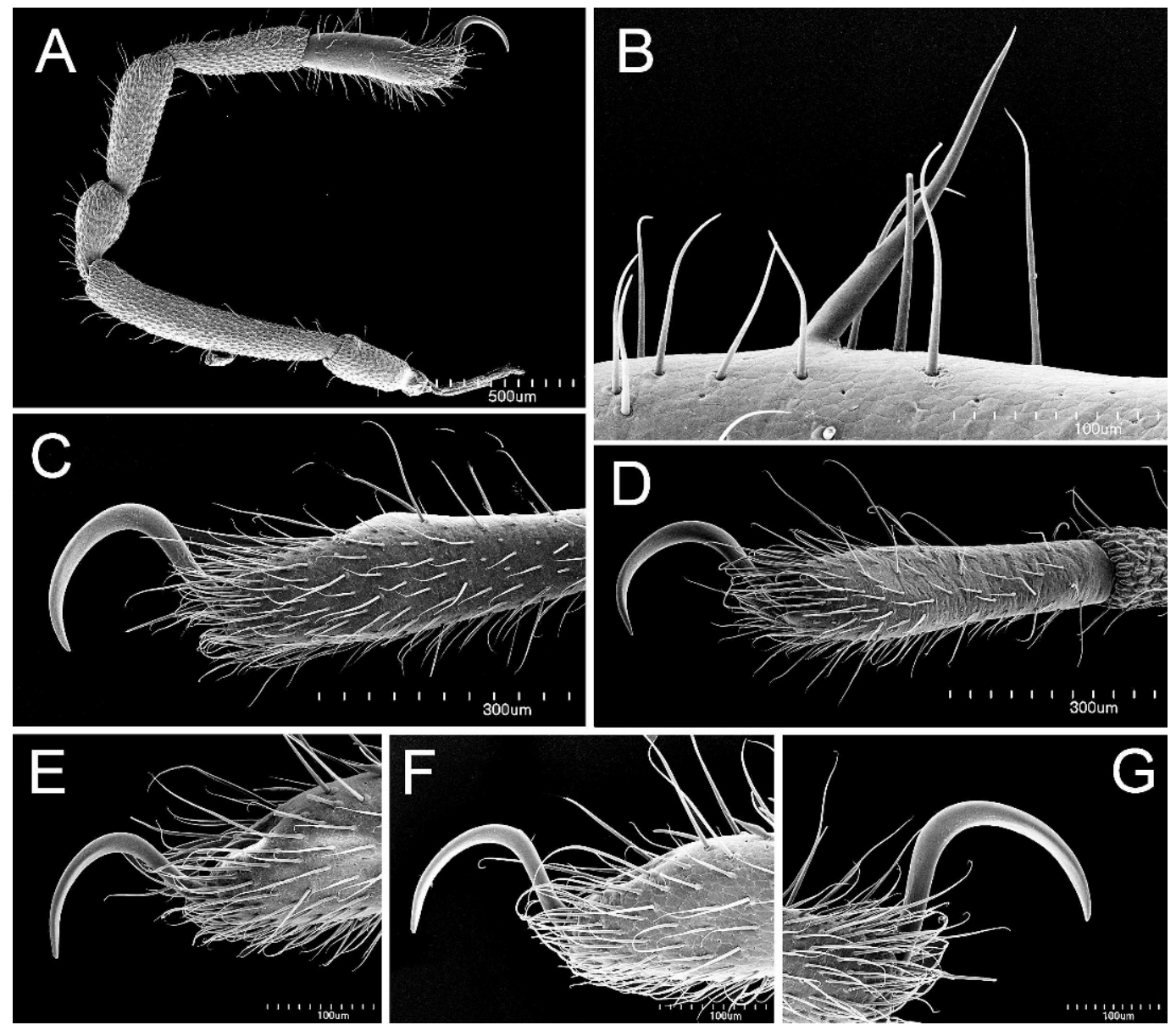

Figure 4. Shearogovea cf. mexasca from Cueva de la Finca. A, left leg IV, male; B, adenostyle; C, left leg I, male; D, left leg IV, female; E, left claw II, male; F, left claw III, male; G, left claw IV, male.

the genus (type locality: Cueva del Nacimiento del Río San Antonio). Whether the second collection from Cueva de la Finca, a nearby cave, represents the same species or not, remains unsolved, as no males are known from the type locality. These two caves are not in the same hill, but the two hills are separated at the surface by $1 \mathrm{~km}$ of valley fill comprised of soil and volcanic boulders, but in the subsurface the limestone is likely contiguous, as is the case of the troglobitic tarantula Hemirrhagus reddelli
(Gertsch, 1973) and the troglobitic schizomid Stenochrus firstmani (Rowland, 1973) (Rowland and Reddell, 1980). However, until males from both caves or molecular data become available, I refer to the specimens from the second locality as Shearogovea cf. mexasca.

Etymology. The generic name is a combination of the last name of arachnologist and myriapodologist William Shear, to whom this genus is dedicated - in honor of his many contributions to the study of $\mathrm{Cy}$ - 
phophthalmi, which include, among many other aspects, four genera and 30 speciesand the termination -ogovea, typical of neogoveid and ogoveid species. Gender is feminine.

Remarks. The type species of the genus was originally described in the genus Neogovea Hinton, 1938, although in the original description Shear (1977:175) stated that "The general appearance of the animal suggests intermediacy between Metasiro americanus and the other species of Neogovea, and a new generic name may be warranted when males are discovered." In the following paper describing the males from a nearby cave, Shear (1980:17) also pointed out that "The adenostyle of $N$. mexasca is not like that of the epigean species, but more like that found in species of Siro. I cannot say if this represents a specialization or the retention of an ancestral form. Certainly, N. mexasca is far separated from the South American species and could be a very ancient relict of an original Neogovea stock - predating both the origin of the brushlike adenostyle and the extensive coxal fusion of the South American species."

After studying the evolution of Neogoveidae and its related families (Ogoveidae and Troglosironidae) (Giribet et al., in press) we now understand that major differences exist between the Amazonian genus Neogovea and Shearogovea gen. nov. These differences are not restricted to the adenostyle, so characteristic in the genus Neogovea (see Jocqué and Jocqué, 2011). The free coxae II distinguishes Shearogovea from most neogoveid genera, although the Brazilian Canga DaSilva, Pinto-da-Rocha \& Giribet, 2010 and the North American Metasiro Juberthie, 1960 also show this condition (Juberthie, 1960; DaSilva et al., 2010). This character state is shared with pettalids, troglosironids, and most sironids (except for Iberosiro de Bivort \& Giribet, 2004 and Paramiopsalis
Juberthie, 1962), but differs from stylocellids and ogoveids, which, like most neogoveids, show fusion to the coxae of legs III (which are always fused to coxae of legs IV) (Giribet and Boyer, 2002). The lack of dentition in the claw of walking leg II and lack of any sort of opisthosomal exocrine glands, now interpreted as synapomorphies of the clade including these three families, also removes Shearogovea from the family Neogoveidae, as proposed by Benavides and Giribet (2007). The lack of jagged dentition in the cheliceral mobile digit and the absence of opisthosomal exocrine glands are two other character states differing from neogoveids and troglosironids.

The placement of Shearogovea gen. nov. in the cladistic analysis of Giribet and Boyer (2002) was rather unresolved, and under their "root 2", would have resulted in an unresolved position with Parasiro and a clade containing ogoveids, neogoveids, troglosironids and stylocellids. A recent analysis combining molecular data and morphology (the former not available for Shearogovea gen. nov.) shows again an unstable phylogenetic position of Shearogovea gen. nov., but it does not group with neogoveids or with any of the related families Ogoveidae and Troglosironidae (Giribet et al., in press). A relationship to the Laurasian family Sironidae is, however, plausible, given the data available at the moment, which would reinforce the idea of Shearogovea gen. nov. being a Laurasian relict.

\section{ACKNOWLEDGMENTS}

Abel Pérez-González, Rudy Jocqué, and Ricardo Pinto-da-Rocha provided comments that helped to improve an earlier version of this article. Samantha Edelheit and Jonathan Losos are acknowledged for their help with the handling and publication of this paper. This work has been possible in large part due 
to a grant from the National Science Foundation (DEB-0236871).

\section{LITERATURE CITED}

Benavides, L. R., And G. Giribet. 2007. An illustrated catalogue of the South American species of the cyphophthalmid family Neogoveidae (Arthropoda, Opiliones, Cyphophthalmi) with a report on 37 undescribed species. Zootaxa 1509: 1-15.

Cokendolpher, J. C., And V. F. Lee. 1993. Catalogue of the Cyphopalpatores and Bibliography of the Harvestmen (Arachnida, Opiliones) of Greenland, Canada, U.S.A., and Mexico. Lubbock, Texas, Vintage Press.

DaSilva, M. B., R. Pinto-da-Rocha, and G. Giribet. 2010. Canga renatae, a new genus and species of Cyphophthalmi from Brazilian Amazon caves (Opiliones: Neogoveidae). Zootaxa 2508: 45-55.

Giribet, G. 2000. Catalogue of the Cyphophthalmi of the World (Arachnida, Opiliones). Revista Ibérica de Aracnología 2: 49-76.

Giribet, G. 2003. Karripurcellia, a new pettalid genus (Arachnida: Opiliones: Cyphophthalmi) from Western Australia, with a cladistic analysis of the family Pettalidae. Invertebrate Systematics 17: 387-406.

Giribet, G. 2007a. Cyphophthalmi, pp. 92-95. In R. Pinto-da-Rocha, G. Machado, and G. Giribet eds. Harvestmen: The Biology of Opiliones. Cambridge, Massachusetts, Harvard University Press.

Giribet, G. 2007b. Neogoveidae Shear, 1980, pp. 95-97. In R. Pinto-da-Rocha, G. Machado, and G. Giribet eds. Harvestmen: The Biology of Opiliones. Cambridge, Massachusetts, Harvard University Press.

Giribet, G., AND S. L. Boyer. 2002. A cladistic analysis of the cyphophthalmid genera (Opiliones, Cyphophthalmi). Journal of Arachnology 30: 110-128.

Giribet, G., And A. B. Kury. 2007. Phylogeny and biogeography, pp. 62-87. In R. Pinto-da-Rocha, G. Machado, and G. Giribet eds. Harvestmen: The Biology of Opiliones. Cambridge, Massachusetts, Harvard University Press.

Giribet, G., P. Sharma, L. R. Benavides, S. L. Boyer, R. M. Clouse, B. L. De Bivort, D. Dimitrov, G. Y. Kawauchi, J. Y. Murienne, and P. J. SchwendinGER. in press. Evolutionary and biogeographic history of an ancient and global group of arachnids (Arachnida, Opiliones, Cyphophthalmi) with a new taxonomic arrangement. Biological Journal of the Linnean Society.
Jocqué, M., AND R. Jocqué. 2011. An overview of Neogovea species (Opiliones: Cyphophthalmi: Neogoveidae) with the description of Neogovea virginie n. sp. from French Guiana. Zootaxa 2754: 41-50.

Juberthie, C. 1960. Contribution a l'étude des opilions cyphophthalmes: Description de Metasiro gen. n. Bulletin du Muséum National d'Histoire Naturelle, 2e série 32: 235-241.

Juberthie, C. 1970. Les genres d'opilions Sironinae (Cyphophthalmes). Bulletin du Muséum National d'Histoire Naturelle, 2 e série 41: 1371-1390.

Kury, A. B., And J. C. Cokendolpher. 2000. Opiliones, pp. 137-157. In J. E. Llorente Bousquets, E. González Soriano, and N. Papavero eds. Biodiversidad, Taxonomía y Biogeografía de Artrópodos de México: Hacia una síntesis de su conocimiento. Volúmen II. Universidad Nacional Autonoma de Mexico, Mexico, D.F., México.

Morales Soto, M. 1980. Contribución al conocimiento de los Opiliones de la República Mexicana (Arachnida: Phalangida), pp. 1-212, Universidad Nacional Autónoma de México, México, D.F.

Rambla, M., and C. Juberthie. 1994. Opiliones, pp. 215-230. In C. Juberthie, and V. Decu eds. Encyclopaedia Biospeologica. Moulis-Boucarest, Société de Biospéologie.

Rowland, J. M., and J. R. Reddell. 1980. The Order Schizomida (Arachnida) in the New World. 3. Mexicanus and Pecki Groups (Schizomidae, Schizomus). Journal of Arachnology 8: 1-34.

Schwendinger, P. J., G. Giribet, and H. Steiner. 2004. A remarkable new cave-dwelling Stylocellus (Opiliones, Cyphophthalmi) from Peninsular Malaysia, with a discussion on taxonomic characters in the family Stylocellidae. Journal of Natural History 38: 1421-1435.

SheAR, W. A. 1977. The opilionid genus Neogovea Hinton, with a description of the first troglobitic cyphophthalmid from the western hemisphere (Opiliones, Cyphophthalmi). Journal of Arachnology 3: 165-175.

SHEAR, W. A. 1979. Huitaca ventralis, n. gen., n. sp., with a description of a gland complex new to cyphophthalmids (Opiliones, Cyphophthalmi). Journal of Arachnology 7: 237-243.

SHEAR, W. A. 1980. A review of the Cyphophthalmi of the United States and Mexico, with a proposed reclassification of the suborder (Arachnida, Opiliones). American Museum Novitates 2705: $1-34$. 